\title{
Eco-distribution of Vitellaria paradoxa (G.F. Gaertn) in Kwara State, Nigeria
}

\author{
Ezekiel J. ADERIBIGBE*, Olamide O. FOLARIN, \\ Clement O. OGUNKUNLE, Felix A. OLADELE \\ University of Ilorin, Department of Plant Biology, Faculty of Life Sciences, PMB 1515, Ilorin, Nigeria; \\ aderibigbe_ezekiel@yahoo.com (*correspondingauthor);faoladele@yahoo.com; seyeogunkunle@gmail.com; folarinmide@gmail.com
}

\begin{abstract}
The conservation status of Vitellaria paradoxa in Kwara state was studied. The frequency ranged from $20 \%$ at Offa and Ilofa to $100 \%$ at Jebba and Kaiama, as the shea tree occurred twice in the ten sampling points at Offa and Ilofa, but occurred in all sampled sites at Jebba and Kaiama. The highest tree mean density of 34 trees/ha was noted at Kaiama and the lowest at Offa 4 trees/ha. The overall mean densities of the species was 13.33 trees/ha. These show that Vitellaria paradoxa trees were more conserved towards the Northern part of the state than the Southern part. The majority of the trees were between $(21-30 \mathrm{~cm})$ diameter class, which indicated that they were saplings and very few were around $(<10 \mathrm{~cm})$ diameter class. The results showed low population of seedlings in the state, especially at the Northern part of the state. This might be due to trees' removal for farming activities, uncontrolled incessant bush burning and trampling by grazing live stocks in the areas.
\end{abstract}

Keywords: conservation, density, frequency, population

\section{Introduction}

The alarming rate at which various plant species are removed from their natural habitats has been documented by many authors (Ledig, 1992; Mulongoy et al., 1992; Mace, 1995; Orji and Ugbaja, 2008).

Perhaps the most heavily exploited of the forest products are the trees, which form the main structural component of our wooded lands. Timber species are converted on a daily basis into logs and boards of various grades. Rough timbers are equally removed on a regular basis for conversion into papers (Anon, 1990), or used as fuel woods. Wood used for cooking accounts for nearly $80 \%$ of the energy consumption in Nigeria (Akinbode, 1991). At the moment, there is no real alternative to fuel wood for cooking, especially in the rural areas (Akinbode, 1991), nor is there any possibility of reducing pressure on the timber species. The increase in Nigeria population will continue to increase the demand for these valuable resources that unfortunately are limited in supply.

The extent of the loss in biodiversity and genetic resources can be imagined through a reference to the list of 480 endangered plant species (including over 100 tree species) complied by Gbile et al. (1981). Going by our present attitudes towards the natural vegetation, scientists have estimated that in less than two decades more than a million species of plants and animals will become extinct
(Dallmeier, 1992). Most of these extinctions will of course occur in the tropics where the pressure of poverty and population growth, as well as lack of technical and scientific infrastructure, make conservation extremely difficult. Such conservation efforts are often further hampered by the absence of basic information on the biological resources most in need of protection (Ogunkunle and Oladele, 2004).

An accurate picture of the status of plants and the trends that are impacting on them is difficult to determine. Indeed, we do not yet know the exact number of plant species in the world, but estimated currently at 370,000 known species (Wilson, 1992). However, it is predicted that as many as two-thirds of the world's plant species are in danger of extinction during the course of the 21 st century (Blackmore et al., 2000).

Extinction and declines in plant diversity is due to a range of factors including population growth, high rates of habitat modification and deforestation, over-exploitation, the spread of invasive alien species, pollution and climate change. The Millennium Ecosystem Assessment noted that approximately $60 \%$ of the ecosystem services evaluated are being degraded or used unsustainably. The degradation of ecosystem services often causes significant harm to human well-being and represents a loss of a natural asset or wealth of a country. The assessment also noted a continual decline in the status of provisioning services of the environment, especially wild foods, timber, cotton, wood-fuel, genetic resources, and medicine. It is clear that the overall trend for plant diversity is declining. 
504

The current global attention on the conservation and sustainability of biodiversity particularly in the tropical forests is a consequence of the threat posed by overexploitation. This might lead to depletion of such trees if allowed to go on unchecked resulting also in the elimination of other flora or fauna which depend on such trees for survival. Investigations were therefore conducted to evaluate the effects of such uncontrolled exploitation on Vitellaria paradoxa and its conservation status in Kwara State, Nigeria, by analysing plot parameters including tree frequency distribution, tree density, relative frequency and diameter class distribution of trees at breast height at different sampling points.

\section{Materials and Methods}

\section{Description of the study area}

The study area is Kwara State in Nigeria (Fig. 1), located between latitudes $8^{\circ} 30^{\prime} \mathrm{N}$ and longitude $5^{\circ} 00^{\prime} \mathrm{E}$ with a land area of approximately $36,825 \mathrm{~km}^{2}$. The area falls into the Southern Guinea Savanna region of Nigeria which has been identified as the major shea butter zone of Nigeria (Keay et al., 1989). The temperature of the area is uniformly high, ranging from $25{ }^{\circ} \mathrm{C}$ to $30^{\circ} \mathrm{C}$ throughout the wet season except in July and August, and in the dry season it ranges between $33{ }^{\circ} \mathrm{C}$ to $34^{\circ} \mathrm{C}$ (Akpenpuun and Busari, 2013).

\section{Sampling design and data collection}

The study was carried out between March and May, 2014 in 10 communities of Kwara State of Nigeria (Fig. 1).
The communities (study locations) comprise Afon (site 1), Ilofa (site 2), Ilorin (site 3), Iponrin (site 4), Jebba (site 5), Kaiama (site 6), Lafiagi (site 7), Offa (site 8), Omu-Aran (site 9) and Patigi (site 10). The 10 communities/sites can be grouped into 3 agro-ecological zones as presented in Table 1.

At every designated site, 10 sample plots $\left(2,500 \mathrm{~m}^{2}\right)$ were demarcated using systematic random sampling according to Chazdon et al. (2005), Johnson and Bhattacharyya (2001) and Aleza et al. (2015). The first plot was randomly located and the subsequent plots were established systematically at least $100 \mathrm{~m}$ apart from previously established plot. In each plot, all stands of $V$. paradoxa were identified and enumerated for the Diameter at Breast Height $(\mathrm{DBH})$ and tree density.

\section{Data analysis}

The frequency and relative frequency of $V$. paradoxa in each study location was determined according to Marcy (1988). Tree density based on the method of Odebiyi et al. (2004) was calculated, while diameter at breast height (DBH) was determined according to Ihenyen $e t$ al. (2009). The mean diameter $\left(\mathrm{D}_{\mathrm{m}}\right)$ per location was computed using the following equations:

$$
D B H=\frac{\text { Girth }}{\pi} ; \operatorname{Dm}(\mathrm{cm})=\sqrt{ }\left[\frac{i}{n} \sum_{i=1}^{n} d^{2}\right]
$$

where $\pi$ is a constant of 3.142 , ' $n$ ' is the number of individuals of a considered group and ' $d i$ ' is the diameter of the individual tree ( $i$ ').

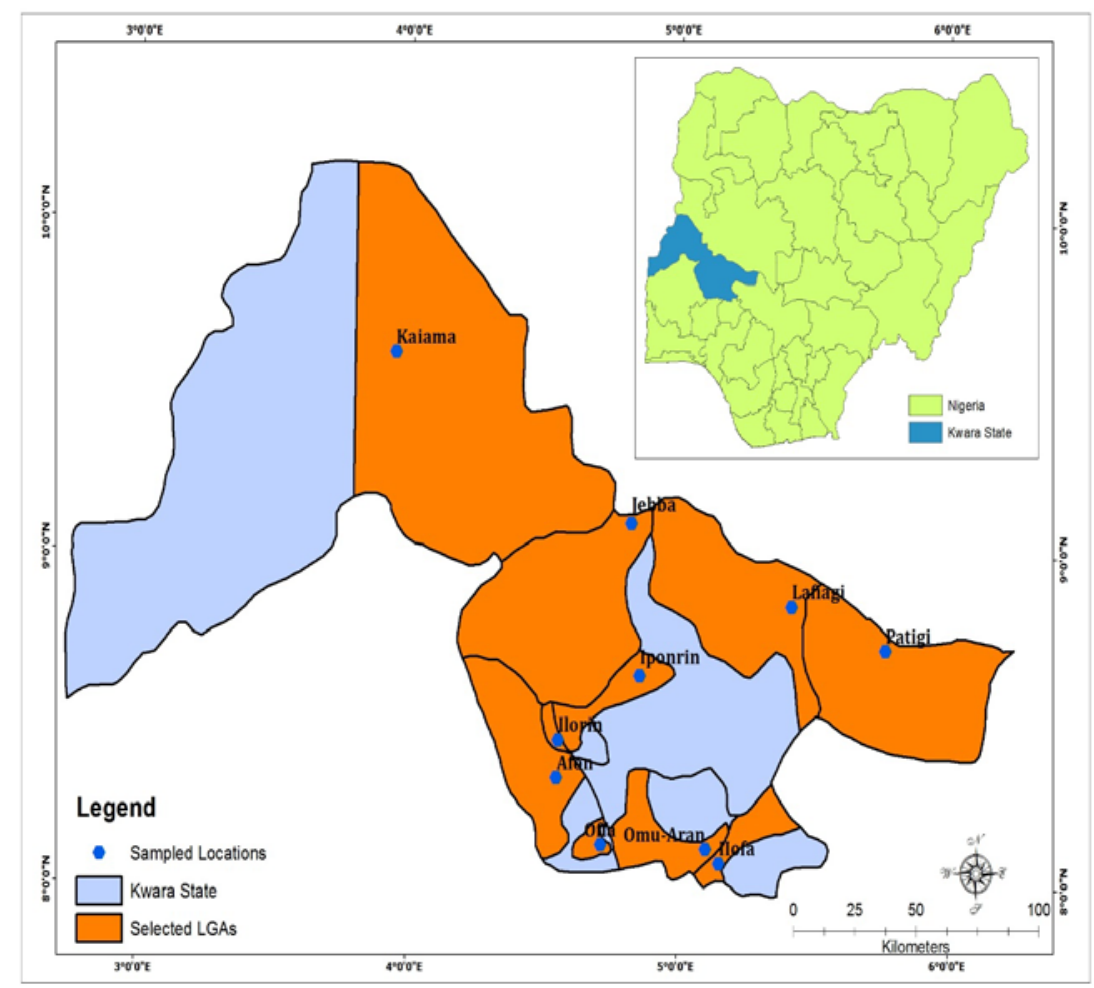

Fig 1. Map of Kwara State showing location of the study sites 
Table 1. Grouping of the study locations based on agro-ecological zones

\begin{tabular}{cccc}
\hline Agro-ecological zone & Study location & Population (NPC, 2006) & Coordinates \\
\hline & Offa & 113,830 & $8.1393^{\circ} \mathrm{N}, 4.7174^{\circ} \mathrm{E}$ \\
i. Moist woodland & Omu-Aran & 14,477 & $8.1402^{\circ} \mathrm{N}, 5.0963^{\circ} \mathrm{E}$ \\
& Ilofa & $\mathrm{NA}$ & $8.0933^{\circ} \mathrm{N}, 5.1458^{\circ} \mathrm{E}$ \\
\hline & Afon & $\mathrm{NA}$ & $8.3167^{\circ} \mathrm{N}, 4.5333^{\circ} \mathrm{E}$ \\
& Ilorin & 777,667 & $8.4799^{\circ} \mathrm{N}, 4.5418^{\circ} \mathrm{E}$ \\
& Iponrin & $\mathrm{NA}$ & $8.6408^{\circ} \mathrm{N}, 4.8210^{\circ} \mathrm{E}$ \\
& Lafiagi & 102,799 & $8.8525^{\circ} \mathrm{N}, 5.4044^{\circ} \mathrm{E}$ \\
& Patigi & 28,285 & $8.7211^{\circ} \mathrm{N}, 5.7563^{\circ} \mathrm{E}$ \\
& Kaiama & 21,89 & $9.6062^{\circ} \mathrm{N}, 3.9419^{\circ} \mathrm{E}$ \\
& Jebba & 22,488 & $9.1193^{\circ} \mathrm{N}, 4.8261^{\circ} \mathrm{E}$ \\
\hline
\end{tabular}

\section{Results}

\section{Determination of tree frequency}

Table 2 shows the frequency distribution of Vitellaria paradoxa in 10 local Government area of Kwara State. Jebba and Kaiama recorded the occurrence of the plant in all the sampling points, which leads to the highest percentage frequency in the area, followed by Patigi and Lafiagi. On the other hand, Ilofa and Offa recorded the lowest percentage frequency due to low rate of occurrence of the plant in the area. The plant occurred just twice in all the sampling points in these areas of the State. Omu-Aran and Afon recorded the same percentage frequency which was less than that of Iponrin but was higher than that of Ilorin which falls below average.

\section{Relative frequency}

Lowest relative frequency of $V$. paradoxa was recorded at Offa and Ilofa, while Jebbaand Kaiama had the highest relative frequency. There were Lafiagi and Patigi which had the relative frequency lower than that of Kaiama and Jebba, and Iponrin followed closely. Afon and Omu-Aran recorded the same relative frequency which was lower than that of Iponrin and also Ilorin which was higher in relative frequency than that of Offa and Ilofa.

\section{Density distribution}

The tree density of the plant varied from one sampling point to the other. The lowest mean density was recorded at Offa because $V$. paradoxa occurred in only two sampling points out of the 10 sampling points studied in the area, followed by Ilofa. The highest mean density was recorded in Kaiama and Jebba which was due to occurrence of $V$. paradoxa in all the 10 sampling points in the area. Followed by Lafiagi and Patigi also recorded a very high mean density though lower than that of Kaiama and Jebba. Iponrin recorded a density a little higher than the overall average density of all the studied areas. Afon, Omu-Aran and Ilorin recorded mean densities lower than the overall mean density. The mean densities of the species was 13.33 trees/ha (Table 2).

\section{Diameter at breast height}

Table 3 shows the various diameter class distributions of trees at breast height in all the studied areas. In Afon, most trees found belong to seedling and sapling class, whereas the highest population of seedling was recorded in this studied area. In Ilofa, Ilorin, Iponrin, Omu-Aran and Patigi, few numbers of seedlings was found in these areas also. Majority of the plant in Ilofa were between sapling and seedling, though very few belong to adult class. Kaiama had trees which ranged between sapling and adult class, but no seedlings were recorded in this area. Also, no seedling was recorded in areas such as Jebba, Lafiagi, and Offa, though trees of higher diameter class were found in all these areas. Kaiama and Ilorin were the only areas that recorded trees within the highest diameter class. The majority of tree in all studied areas were saplings, and very few were around $(<10$ $\mathrm{cm})$ diameter class, which showed low population of seedlings in the state. The highest diameter class present in the studied areas was $(81-90 \mathrm{~cm})$ diameter class; there was no tree above $(91 \mathrm{~cm})$ diameter class.

Table 2. Frequency and density (trees/ha) of $V$.paradoxa according to agro-ecological zone

\begin{tabular}{|c|c|c|c|c|}
\hline Agro-ecological zone & Study location & Frequency (\%) & Relative frequency (\%) & Tree density (plants/ha) \\
\hline \multirow{3}{*}{ i. Moist woodland } & Offa & 20 & 3 & $4.0 \pm 2.7$ \\
\hline & Omu-Aran & 60 & 9 & $9.2 \pm 2.9$ \\
\hline & Ilofa & 20 & 3 & $5.2 \pm 3.6$ \\
\hline \multirow{7}{*}{ ii. Southern Guinea Savanna } & Afon & 60 & 9 & $10.4 \pm 3.53$ \\
\hline & Ilorin & 40 & 6 & $7.2 \pm 3.1$ \\
\hline & Iponrin & 80 & 12 & $15.2 \pm 3.4$ \\
\hline & Lafiagi & 90 & 14 & $24.4 \pm 4.4$ \\
\hline & Patigi & 90 & 14 & $20.4 \pm 4.3$ \\
\hline & Kaiama & 100 & 15 & $34.0 \pm 4.6$ \\
\hline & Jebba & 100 & 15 & $18.8 \pm 3.0$ \\
\hline
\end{tabular}


Table 3. Distribution of diameter at breast height $(\mathrm{cm})$ for $V$. paradoxa

\begin{tabular}{|c|c|c|c|c|c|c|c|c|c|c|}
\hline \multirow[t]{2}{*}{ Class } & \multicolumn{3}{|c|}{$\begin{array}{c}\text { Moist woodland } \\
\text { Mean diameter }\left(\mathrm{D}_{\mathrm{m}}\right)(\mathrm{cm})\end{array}$} & \multicolumn{7}{|c|}{$\begin{array}{l}\text { Southern Guinea Savanna } \\
\text { Mean diameter }\left(D_{\mathfrak{m}}\right)(\mathrm{cm})\end{array}$} \\
\hline & Offa & Omu Aran & Ilofa & Afon & Ilorin & Iponrin & Lafiagi & Patigi & Kaiama & Jebba \\
\hline$<10$ & 0 & 6.93 & 7.6 & 7.6 & 7.36 & 8.42 & 0 & 8.35 & 0 & 0 \\
\hline $11-20$ & 0 & 15.35 & 13.05 & 15.03 & 15.63 & 17.61 & 14.48 & 15.82 & 15.68 & 15.35 \\
\hline $21-30$ & 26.40 & 25.87 & 23.79 & 26.57 & 25.62 & 25.49 & 24.27 & 27.54 & 24.98 & 24.32 \\
\hline $31-40$ & 35.18 & 31.5 & 35.25 & 0 & 0 & 35.42 & 33.84 & 36.63 & 35.63 & 35.77 \\
\hline $41-50$ & 45.70 & 0 & 0 & 0 & 0 & 46.12 & 45.66 & 45.60 & 44.95 & 45.74 \\
\hline $51-60$ & 55.02 & 0 & 56.30 & 0 & 55.58 & 55.51 & 55.20 & 56.46 & 55.46 & 54.51 \\
\hline $61-70$ & 66.91 & 0 & 0 & 0 & 65.23 & 66.61 & 64.34 & 0 & 66.01 & 65.37 \\
\hline $71-80$ & 0 & 0 & 0 & 0 & 0 & 76.33 & 75.3 & 0 & 73.5 & 77.99 \\
\hline $81-90$ & 0 & 0 & 0 & 0 & 82.1 & 0 & 0 & 0 & 84.10 & 0 \\
\hline $91-100$ & 0 & 0 & 0 & 0 & 0 & 0 & 0 & 0 & 0 & 0 \\
\hline$>100$ & 0 & 0 & 0 & 0 & 0 & 0 & 0 & 0 & 0 & 0 \\
\hline
\end{tabular}

\section{Discussion}

The conservation status of Vitellaria paradoxa in Kwara state revealed that the frequency distribution and density of the plant varies from one area to the other.

The lowest frequency of $V$. paradoxa was recorded at Ilofa and Offa respectively which stand at $20 \%$ followed by Ilorin with $40 \%$ frequency, which shows that the plant is Vulnerable (VU) or Threatened (T) in the areas, according to World Conservation Union (WCU) red list (Anonymous, 2008). While at Afon and Omu Aran the frequency stands at $60 \%$, which shows that the plant is Near Threatened (NT) in the areas according to World Conservation Union (WCU) red list (Anonymous, 2008). The highest frequency of occurrence at Kaiama and Jebba at $100 \%$, also at Patigi and Lafiagi at $90 \%$, and Iponrin with $80 \%$ frequency, show that the plant is of Least Concern (LC) in the areas according to World Conservation Union (WCU) red list (Anonymous, 2008).

The mean densities of the species was 13.33 trees/ha. The results compared with the density of Vitellaria paradoxareported byPopoola and Tee (2001), surveying Vitellaria distribution in Benue state, Nigeria, reported a density of 23-105 stands/ha. In Uganda, the density of Vitellaria in the vegetation ranged from 0.3 trees/ha in wetlands to 12.0 trees/ha in near compound use (Nkuutu, 2000). Also, Odebiyi et al. (2004) reported a density of 4 stand/ha in a cultivated land and 5 stand/ha in a fallow land use. Higher density between 10-18 stands/ha was shown at Niger state.

The results showed that there were 34 trees/ha in Kaiama and the lowest density was at Offa with 4 trees/ha. These results imply that there was preponderance of the plant in northern axis of Kaiama, Lafiagi, Patigi and Jebba, relative to southern axis, which agree with the work of Odebiyi et al. (2004), who noted that $V$. paradoxa always enjoy certain degrees of protection in the northern part than the south because Elaeis guineensis (oil palm tree) is a suitable alternative as a source of edible oil.

In all the area surveyed, saplings of Vitellaria were very low especially at the northern part of the state. This may be due to the removal for farming activities, uncontrolled incessant bush burning and trampling by grazing live stocks in the areas, which may aggravate the threat of extinction that the plant is been subjected to. This agreed with the work of Oni (2004), who suggested that the absence of lower diameter class of Vitellaria shows poor rate of natural succession, as many of the seedlings rarely develop to pole sizes or are allowed to mature to adult size trees. The absence of the lower diameter classes in several parklands in West African countries indicated to be due to decreasing annual rainfall, desert encroachment and poor natural regeneration (Baumer, 1990; Kessler and Boni, 1994). More so, they are not domesticated at present and the larger trees are being exploited and destroyed for agronomic crops. In the southern part of the state, Vitellaria are not particularly protected because of its low product value, while in the north, it is in danger due to urban demand for charcoal, preferential utilization for fuel (owing to its high calorific value) and removal for farming activities.

In view of the problems associated with conservation of $V$. paradoxa in Kwara State, there is need for the farmers in the state and even the general population to be sensitized on the importance of conserving, preserving and protecting the trees, seedlings and saplings of $V$. paradoxa so as to maintain a stable population especially in the northern part of the state. It is important to undertake further research especially on propagation so that the juvenile phase of the $V$. paradoxa can be reduced in order to curtail the reliance on natural regeneration. This may encourage more farmers to start planting shea trees instead of waiting for coppices.

There is need therefore, for the different stakeholders at various levels to come up with more holistic management program that will enhance reduced pressure on various important forest genetic resources is long overdue.

Government should also find alternative means of cooking using other energy sources such as solar cookers and bio-energy gas stoves and charcoal briquette sawdust and low-density coal which would greatly reduce the cutting down of shea trees for charcoal and firewood which is usually associated with the traditional cooking methods. Government also should be more involved in the work of conservation by providing supporting funds because heavy financial inputs are actually needed in order to execute laudable conservation practices. Much has been done in order to raise fund by Non-Governmental Organization (NGOs), but these funds are not usually sufficient for the completion of these strategies. 
The conservation of Vitellaria paradoxa in Kwara State cannot be effective without the active participation of local people and other stakeholders. The seeming ignorance or negligence of the people to the economics of these plants resulting in the lack of concern of the people to the disappearance of threatened species has exacerbated the problem, thereby creating enormous conservation challenges. In Kwara State, the destruction rate of the environment has so far exceeded the breeding and recovery rate that the situation can only be corrected by drastic measures and determined actions, which will be effected through environmental education and training of the masses so that they will develop true consciousness of their role in their natural and human context. The conservation strategies must address the problems at International, national and local policy level, in-situ and ex-situ conservation methods, thru education and research.

\section{Conclusions}

The information on conservation status of Shea tree in Kwara state obtained in the hereby study showed clearly that the number of Vitellaria trees was the higher towards the northern part of the state, while there were more saplings towards the southern part of the state. The shea tree distribution and occurrence was the highest in the northern part of the state compared to southern part of the state. The data obtained shows that the plant was more conserved towards the northern part of the state than the southern part. Through this investigation, frequency and density data have proved to be good yardsticks to objectively evaluate the status of Vitellaria paradoxa and forest conservative efforts in Kwara state. The trees of $V$. paradoxa are being extracted in large quantities for various uses. The conservation of Vitellaria paradoxa in Kwara State cannot be effective without the active participation of local people and other stakeholders.

\section{References}

Akinbode FO (1991). Testing the efficiency of Nigerian wood stoves. Nigerian Journal Renewable Energy 2(1):43-48.

Akpenpuun TD, Busari RA (2013). Impact of climate on tuber crops yield in Kwara State, Nigeria American International Journal of Contemporary Research 3(10):52-57.

Aleza K, Wala K, Bayala J, Villamor GB, Dourma M, Atakpama W, Akpagana K (2015). Population structure and regeneration status of Vitellaria paradoxa under different land management regimes in Atacora department, Benin. Agroforestry System 89:511-523.

Anonymous (1990). Raw materials sourcing for manufacturing in Nigeria. Raw Materials Research and Development Council, MacMillian Nig. Publishers, Lagos, Nigeria.

Anonymous (2008). IUCN Red List of threatened species. Retrieved 26 February 2017 from www.i ucnredlist.org.

Barrow GJ (2002). Land Degradation, Cambridge University Press, Great Britain UK.

Baumer M (1990). The potential role of agroforestry in combating desertification and environmental degradation with special reference to Africa. Technical Center for Agricultural and Rural CooperationWageningen pp250.
Blackmore S, Bramwell D, Crane P, Dias B, Given FT, Leiva A, Morin NR Pushpangadan P, Raven PH, Samper C, Sarukhan JJ, Simiyu S, Smirnov I, Wyse-Jackson PS (2000). The Gran Canaria Declaration, BGCI, Richmond UK.

Chazdon RL, Brenes AR, Alvarado BR (2005). Effects of climate and stand age on annual tree dynamics in tropical second growth rain forests. Ecology 86:1808-1815.

Dallmeier F (1992). Long term monitoring of biological diversity in tropical forest areas: methods for establishment and inventory of permanent plots. Dallmeier F(Ed), MAB Digest II UNESCO, Paris.

Gbile ZO, Ola-Adams BA, Soladoye MO (1981). List of rare species of Nigeria flora. Research Paper (Forest Series) 47, Forest Research Institute of Nigeria, Ibadan.

Ihenyen J, Okoegwale EE, Mensah JK (2009). Composition of tree species in Ehor Forest Reserve, Edo State, Nigeria. Nature and Science 7(8):818.

Keay RWJ, Onochie CFA, Stanfield DP (1989). Trees of Nigeria: a revised version of Nigeria trees vols 1 and 2. National Press Ltd, Apapa Lagos. Published by the Department of Forestry Research Institute, Ibadan.

Kessler JJ, Boni J (1991). L'agroforesterie au Burkina Faso: bilan et analyse de la situation actuelle (No. 1). Ministère de l'environnement et du tourisme, Direction forêts et reboisement.

Ledig ET (1992). Human impact on genetic diversity in forest Ecosystem. Oikos 63:87-108.

Mace GM (1995). Classification and its role in conservation planning in extinction rates. Lawton J, May RM (Eds). Oxford University Press, New Yorkpp 197-213.

Marcy LE (1988). Distance sampling techniques. Department of the army. Waterways Experiment Station, Corps of Engineers PO Box, 631.

Mulongoy K, Gueye M, Spender D (1992). Biology nitrogen fixation and sustainability of tropical agriculture. IITA Ibadan Nigeria pp 21-46.

Nkuutu D (2000). Indigenous tree management in the Butyrospermum parklands of Northern Uganda with particular reference to the shea butter tree (Vitellaria paradoxa) (BSc Thesis). University of Makerere, Kampala, Ugandapp 82.

Odebiyi JA, Bada SO, Awodoyin RO, Oni PI, Omoloye AA (2004). Population structure of Vitellaria paradoxa Gaertn. F and Parkia biglobosa (Jacq.) Benth. in the agroforestry parklands of Nigerian savanna. West African Journal of Applied Ecology 5(1):31-39.

Ogunkunle ATJ, Oladele FA (2004). Ethnobotanical study of fuelwood and timber wood consumption and replenishment in Ogbomoso, Oyo State, Nigeria. Environmental Monitoring and Assessment 91:223-236.

Oni PI (2004). Initial evaluation of Parkia biglobosa (Jacq) Benth. provenances from West African countries. A poster presentation in a Regional Workshop on Plant Genetic Resources and Food Security in West and Central Africa at IITA Ibadan 26-30 April.

Orji EC, Ugbaja MJ (2008). Effect of intercropping of Mricuna cercupudes with maize on the productivity of maize in the humid. Tropical Journal of Agriculture 2:118-211.

Popoola L, Tee NT (2001). Potentials of Vitellaria paradoxa. Gaertn. in agroforestry systems in Benue State, Nigeria. Nigerian Journal of Ecology 3:65-74.

WilsonEO (1992). The diversity oflife. Penguin, London, UK pp 432. 